Article Type: Research Paper

\title{
External Debt, Exchange Rate, and Unemployment in Selected ASEAN Countries
}

\author{
Malik Cahyadin* and Lely Ratwianingsih
}

\section{OPEN}

\section{AFFILIATION:}

Faculty of Economics and Business, Universitas Sebelas Maret (UNS), Surakarta. Indonesia.

*CORRESPONDENCE:

malikcahyadin@gmail.com

THIS ARTICLE IS AVALILABLE IN:

http://journal.umy.ac.id/index.php/esp

DOI: 10.18196/jesp.21.1.5029

\section{CITATION:}

Cahyadin, M., \& Ratwianingsih, L. (2020). External Debt, Exchange Rate, and Unemployment in Selected ASEAN Countries. Jurnal Ekonomi \& Studi Pembangunan, 21(1), 16-36.

\section{ARTICLE HISTORY}

Received:

20 January 2020

Reviewed:

3 February 2020

14 April 2020

Revised:

17 April 2020

23 April 2020

Accepted:

17 April 2020
Abstract: This research examines the empirical model of external debt, exchange rate, and unemployment in selected ASEAN Countries during 1980-2017. The countries included Indonesia, Malaysia, Thailand and the Philippines. The data were collected from the World Bank publications. The ARDL-ECM and Granger Causality Test (GCT) were employed to address the research objectives. The findings indicated that there were short-term effects on each empirical model (external debt, exchange rate, and unemployment). Furthermore, the stability test exhibited that the models were precise and stable. The GCT result showed that there was a causal between external debt, exchange rate, and unemployment, especially in Indonesia. Moreover, the linkages between external debt, exchange rate, and unemployment in selected ASEAN Countries were comovement. Therefore, the governments are expected to emphasis on macroeconomic policies, such as pro-stability of the exchange rate, external debt risk management, and pro-poor.

Keywords: External debt; Exchange rate; Unemployment; Macroeconomic policy. JEL Classification: F31, F34, J60.

\section{Introduction}

Some developing and developed countries face an increase in external debt as a source of development financing. The low level of external debt is expected to maintain the stability of domestic economic and fiscal sustainability. For example, in 2016, the World Bank showed that United State, United Kingdom, and Japan had a ratio of public debt to GDP above $100 \%$. In contrast, the countries, such as Indonesia Malaysia, Thailand, and the Philippines, have a ratio of public debt to GDP below $60 \%$. Empirically, Malaysia showed that the risk of a high level of public debt could impact negatively on fiscal sustainability and the domestic economy (Baharumshah, Soon, \& Lau, 2017). This condition proves that external debt contributes significantly to the country's macroeconomic indicators. Therefore, this research emphasizes the estimation and the relationship between external debt, exchange rate, and unemployment. Besides, unemployment is one of the important macroeconomic indicators in the ASEAN region, besides economic growth. The high level of unemployment leads to high level of public and private debt to generate business cycle of industry and absorb labour. 
External debt and exchange rate can be a credible economic indicator to enlighten a country's domestic economy. There are some economic variables related to those indicators. Nelasco (2012) explained that the external debt in South Asian Countries tends to increase due to some defining factors, such as population, FDI, international reserve, exchange rate, GDP per capita, GNI per capita, export, and import. Meanwhile, Ramasamy and Abar (2015) identified the factors affecting the exchange rate, namely: interest rate, inflation rate, the balance of payment, employment rate, corruption index, GDP, budget surplus/deficit, tax, and borrowing. Besides, inflation, debt, and exchange rate have a good relationship both in the short- and long-run (Yien, Abdullah \& Azzam, 2017). Therefore, third world countries need to ensure the availability and the continuity of debt management by strengthening some aspects like the institutions, human resources, law, and strategy (Mahmud, 2018).

Four ASEAN countries - Indonesia, Malaysia, Thailand, and the Philippines - undergo an increasing external debt over time. Furthermore, they also go through a fluctuating exchange rate and unemployment. This phenomenon becomes one of the motivations of this research. In addition, three steps of estimations would be executed. The first step was estimating the empirical model of external debt, exchange rate, and unemployment in selected ASEAN countries under ARDL-ECM. The second step was examining the fitted value of the empirical model of external debt, exchange rate, and unemployment. Finally, the Granger Causality Test (GCT) was utilized to estimate the link between the fitted value of external debt, exchange rate, and unemployment. Thus, this research attempt to employ multi-step estimations. To our best knowledge, the multi-step estimations on external debt, exchange rate, and unemployment in ASEAN countries were not used by the previous studies.

The empirical research by Abdoh, Yusuf, Zulkifli, Bulot, and Ibrahim (2016) identified that export had a significant effect on the exchange rate, while interest rate and inflation had an insignificant impact. A different result was obtained by Parveen, Khan, and Ismail (2012), they found that economic growth, inflation, export, and import have a significant effect on the exchange rate. Meanwhile, Patel, Patel, and Patel (2014) described that exchange rate could be influenced by inflation, interest rate, capital account balance, the role of speculators, cost of manufacture, the debt of the country, gross domestic product, political stability and economic performance, employment, the relative strength of other currencies, macroeconomic, and geopolitical events. Thus, this research identifies that the exchange rate in ASEAN is influenced by export, interest rate, inflation, and external debt.

Another empirical research such as Awan, Anjum, and Rahim (2015) explained that in the long-run, the external debt was determined by the fiscal deficit, trade openness, and exchange rate. In contrast, in the short-run, the external debt was influenced by trade openness, exchange rate, and external debt. Abdullahi, Bakar, and Hasan (2015) described that external debt was influenced by the exchange rate, interest rate, saving, and budget deficit both in the short- and long-run. The empirical findings are supported by Mupunga and Roux (2014), and Lau and Lee (2016). Therefore, this research determines that the 
external debt in selected ASEAN countries can be affected by interest rate, exchange rate, and national saving.

Dalmar, Ali, and Ali (2017) have conducted empirical research on the determinants of unemployment. The findings showed that unemployment was influenced significantly by gross domestic product (GDP), population growth, and external debt. Moreover, the gross capital formation and exchange rate were insignificant. Besides, Puspadjuita (2018) explained that the unemployment rate was significantly affected by the proportion of high school and above workforce, while the urbanization rate, industrialization rate, elasticity of labour absorption, and provincial minimum wage had an insignificant effect. Thus, this research analyses the effect of GDP growth, exchange rate, and external debt on unemployment in selected ASEAN Countries.

The main objective of this research is to estimate the linkage between external debt, exchange rate, and unemployment in selected ASEAN Countries during 1980-2017. Moreover, the main findings of the first step of analysis in this research showed that (a) external debt in ASEAN Countries was determined by real interest rate, exchange rate, and national saving, (b) exchange rate in ASEAN Countries were affected by total export, real interest rate, external debt, and inflation, and (c) unemployment in ASEAN Countries was determined by economic growth, exchange rate, and external debt. All findings are supported by previous empirical studies. It means that this research was only using a different method in the form of ARDL-ECM compared to the previous empirical studies. In contrast, this research employed the next step of analysis using the Granger Causality Test between the fitted value of external debt, exchange rate, and unemployment. The second analysis indicated that there was a causal between variables. Thus, the finding becomes a broader analysis compared to the previous study.

Figure 1 illustrates Indonesia, Malaysia, Thailand, and Philippine's external debt growth. Generally, external debt growth in all countries was fluctuating. The external debt in Malaysia and Thailand was relatively significant. Both countries should concern about managing and controlling external debt growth to reduce a negative impact on the domestic economy.

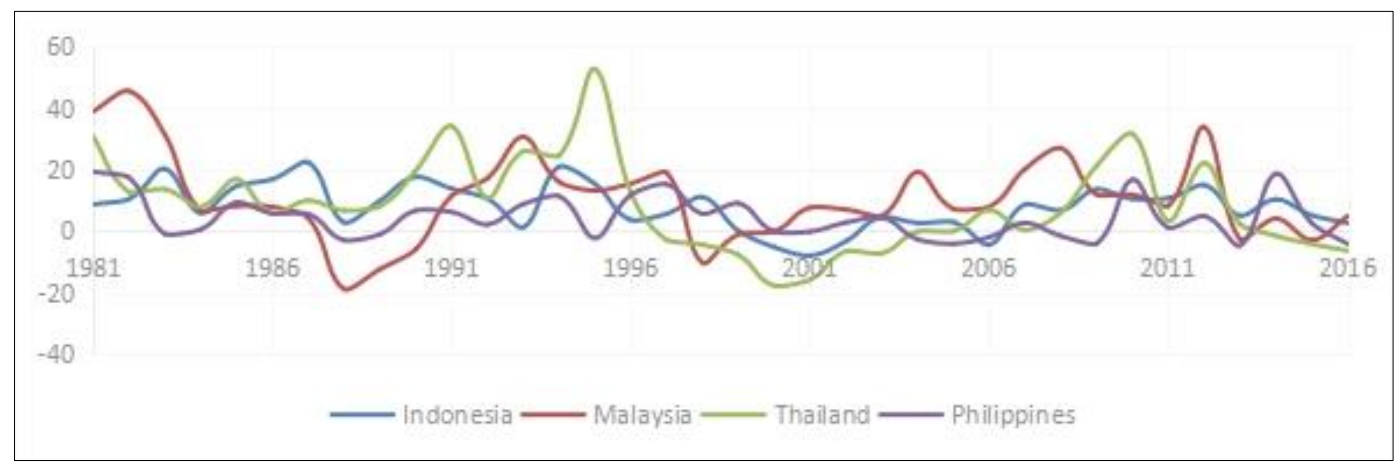

Figure 1 External Debt Growth in ASEAN 4, 1981-2016 (\%)

Source: The World Bank (processed) 
Figure 2 describes the growth of the exchange rate and the unemployment rate in ASEAN4. The trend of growth rate showed fluctuation. The exchange rate fluctuations in Indonesia, the Philippines, and Thailand led to the depreciation of the US dollar. Exchange rate depreciation would risk the domestic economy under the weak fundamental of macro-economy, such as the high unemployment rate, inflation, and deficit of the balance of payments. Meanwhile, the exchange rate in Malaysia was quite stable. However, the exchange rate in Malaysia (RM/US\$) led to a state depreciation.

The unemployment in selected ASEAN countries is relatively fluctuating but tends to decline. Indonesia and Thailand have a relatively high unemployment rate. The governments of those countries need to observe this phenomenon properly. The macroand micro-economy indicators driving unemployment should be adequately managed. Besides, the high unemployment rate will be a burden for the governments to increase the domestic economy significantly and continually.
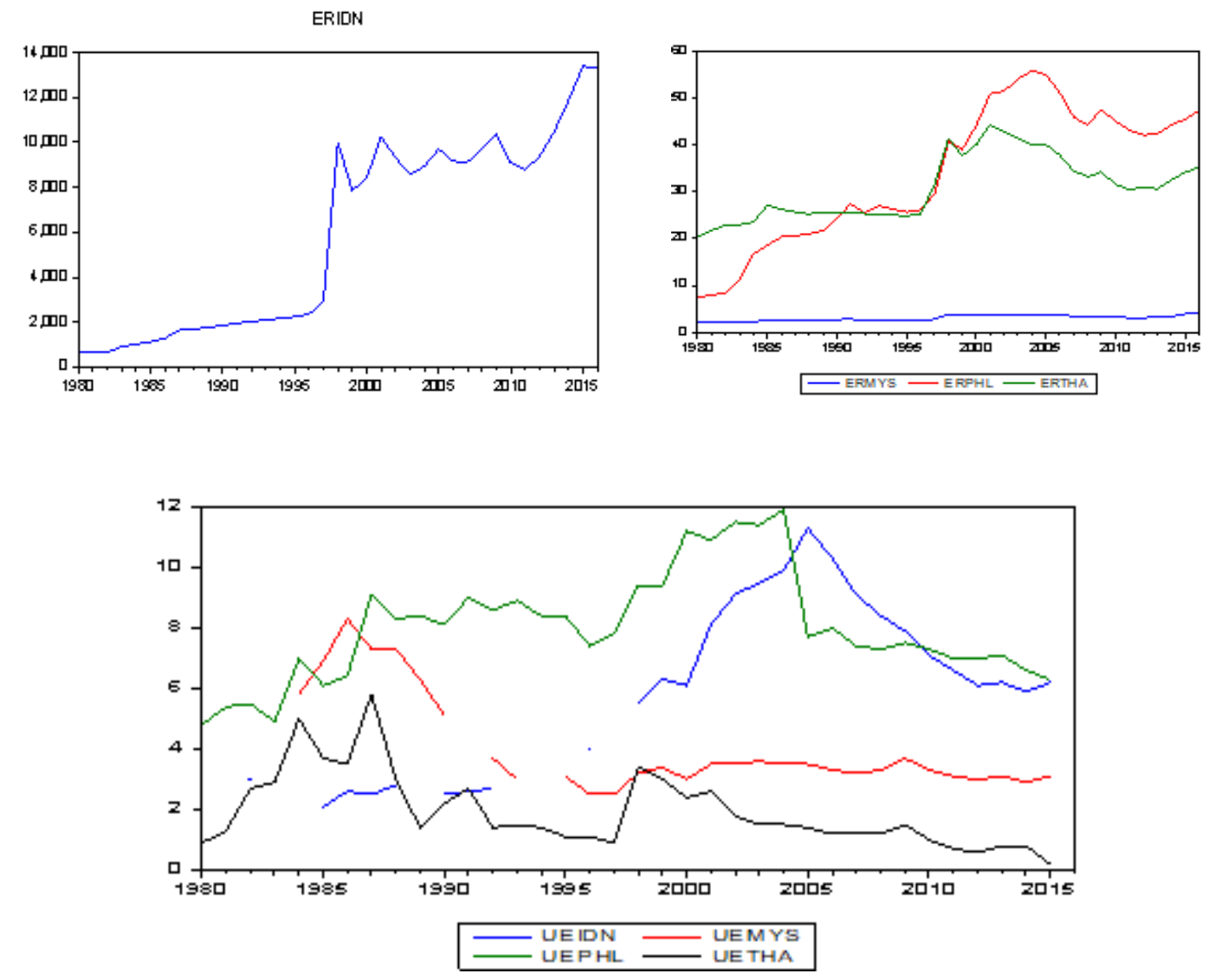

Note: IDN = Indonesia, $\mathrm{MYS}=$ Malaysia, $\mathrm{PHL}=$ the Philippines, $\mathrm{THA}=$ Thailand, $\mathrm{ER}=$ exchange rate, $\mathrm{UE}=$ unemployment rate

Figure 2. Exchange Rate (Local Currency/US\$) and Unemployment Rate (\%), 1980-2016 Source: The World Bank 
This research contributes to the existing literature in several ways. Firstly, three empirical models exhibited the effect of explanatory variables on external debt, exchange rate, and unemployment in selected ASEAN countries during 1980-2017. Secondly, ARDL-ECM and Granger Causality Test were employed to address the research objectives. Finally, this research exhibited the linkage in the form of co-movement between external debt, exchange rate, and unemployment. It would show the co-movement or countermovement of those variables during research periods. Therefore, the contributions are also directed to the macroeconomic policy that should support three policy issues, such as external debt risk management, exchange rate stability, and pro-poor (control of unemployment rate).

\section{Research Method}

\section{Previous Empirical Studies}

Fiscal policy is emphasized to encourage the government's ability to obtain adequate and sustainable development of funding sources. Fiscal instruments that can be employed are tax revenues and external debt (especially public debt). Furthermore, the value of external debt will be closely related to exchange rate fluctuations. It will imply the government's fiscal policy because the government uses foreign currencies, especially US dollars, in external debt contracts. Moreover, the level of external debt and exchange rate fluctuations have implications for the unemployment rate because those indicators will be utilized in production factors in the form of additional cash flow for industry and government programs for the national project. A productive external debt and stability of the exchange rate can promote a significant reduction in the unemployment rate.

The research conducted by Faini and Gressani (1998) identifies that the external debt burdens the Philippines' fiscal. This burden should be reduced and compensated by the stable exchange rate for the anti-inflation and pro-growth policy. Siregar and Pontines (2005) described that the exchange rate was affected by the term of trade, government expenditure, and productivity. Both types of research emphasize the vital role of fiscal in determining external debt. One example of the debt policy is the management and control of external debt for the productive sector. Furthermore, Neaime (2009) explained the critical role of exchange rate and debt management policy. Some economic indicators were used to measure and manage debt ratio to the export, current account ratio to the export, debt ratio to the GDP, export, import, and interest rate. Meanwhile, Benigno and Romei (2012) argued that there were two economic instruments used to control the rate and effect of external debt to the domestic economy, both in the short- and long-term; those instruments were the exchange rate and real interest rate. Therefore, this research focus on the analysis of external debt determinants in selected ASEAN countries under the ARDL-ECM estimation. Furthermore, this research would find that the effect of interest rate, exchange rate, and national saving on external debt may vary between selected ASEAN countries. 
The empirical researches on the correlation and effects of exchange rate on external debt have been estimated by Fida, Khan, and Sohall (2012), Bunescu (2014), Couharde, Rey and Sallenave (2015), Draz and Ahmad (2015), Nwanne and Richard (2015), Odera (2015), Saheed, Sani, and Idakwoji (2015), and Asonuma (2016). The effects of the variables could occur both in the short- and long-run. Therefore, the policymakers in the monetary or fiscal authorities should manage the external debt and maintain the stability of the exchange rate. Hence, this research will analyse the causality between external debt and exchange rate in ASEAN 4 using Granger Causality Test (GCT). The causality results can be classified into three categories, namely: unidirectional, no causality, or bidirectional. This step of analysis becomes the novelty of this research compared to the previous empirical studies. Moreover, the determinant factors of the exchange rate in selected ASEAN countries include export, interest rate, inflation, and external debt.

Frenkel and Ros (2006) revealed that the exchange rate brought a significant effect on unemployment in Latin America. This result is relevant to the research conducted by Chang and Shen (2011), Floyd (2012), and He (2013). The correlation and effect between the exchange rate on unemployment can be referred from Nyahokwe and Newadi (2013), and Ogonna, Idenyi, Ifeyinwa, and Gabriel (2016). Nyahokwe and Newadi (2016), who explained that the exchange rate had a significant effect on unemployment in South Africa. Furthermore, Ogonna et al. (2016) indicated that public debt had a significant impact on unemployment in the long term. In contrast, Aurangzeb and Asif (2013) analysed the effect of inflation, GDP, exchange rate, and population on the unemployment in Pakistan, India, and China. The result indicated that all independent variables had significant effects on unemployment in those countries. Thus, this research would focus on the estimate of the impact of GDP growth, exchange rate, and external debt on unemployment in selected ASEAN countries. ARDL-ECM would be employed. Besides, this research also used the Granger Causality Test (GCT) to analyse the causality between exchange rate and unemployment, external debt, and unemployment in selected ASEAN countries.

Dataset

This research utilized secondary data from the World Bank publications during 1980-2017. The data were used to estimate the equations of external debt, exchange rate, and unemployment in ASEAN 4. The year 1980 was chosen as the initial period of research because, at that time, the ASEAN member countries were still pushing for improvement in domestic economic conditions, primarily related to poverty, unemployment, and inequality as well as energy availability/investment problems (Akrasanee, 1981). Moreover, the ASEAN member countries chosen as the focus of this research were Indonesia, Malaysia, Thailand, and the Philippines. Those countries were categorized as developing countries that made great efforts to stimulate economic growth through external debt.

The description of the research variables can be seen in Table 1. Those variables were written in symbols to simplify the writing in the ARDL-ECM model and Granger Causality Test. The real external debt variable was symbolized with RED, while the exchange rate 
Cahyadin \& Ratwianingsih

External Debt, Exchange Rate, and Unemployment in Selected ASEAN Countries

and unemployment were represented with ER and UER, respectively. Furthermore, the variables of total export, real interest rate, inflation, real national saving, and GDP growth were signified with $\mathrm{X}, \mathrm{RIR}$, INF, RNS, and GDPG, respectively. The four ASEAN countries (Indonesia, Malaysia, Thailand, and the Philippines) were denoted with IND, MYS, THA, and PHL.

\section{Table 1 Description of Research Variables}

\begin{tabular}{|c|c|c|}
\hline Variables & Description & $\begin{array}{l}\text { Measurement } \\
\text { /Unit }\end{array}$ \\
\hline $\begin{array}{l}\text { Total } \\
\text { external } \\
\text { debt }\end{array}$ & $\begin{array}{l}\text { Total external debt is debt owed to non-residents repayable in currency, goods, } \\
\text { or services. Total external debt is the sum of public, publicly guaranteed, and } \\
\text { private nonguaranteed long-term debt, use of IMF credit, and short-term debt. } \\
\text { Short-term debt includes all debt having an original maturity of one year or less } \\
\text { and an interest in arrears on long-term debt. }\end{array}$ & $\begin{array}{l}\text { Data are in } \\
\text { current U.S. } \\
\text { dollars. }\end{array}$ \\
\hline $\begin{array}{l}\text { Real } \\
\text { external } \\
\text { debt }\end{array}$ & $\begin{array}{l}\text { Total external debt/Consumer Price Index. Consumer price index reflects } \\
\text { changes in the cost to the average consumer of acquiring a basket of goods and } \\
\text { services that may be fixed or changed at specified intervals, such as yearly. The } \\
\text { Laspeyres formula is generally used (Consumer Price Index; } 2010=100 \text { ). }\end{array}$ & $\begin{array}{l}\text { Data are in } \\
\text { constant U.S. } \\
\text { dollars. }\end{array}$ \\
\hline $\begin{array}{l}\text { Exchange } \\
\text { rate }\end{array}$ & $\begin{array}{l}\text { The official exchange rate refers to the exchange rate determined by national } \\
\text { authorities or to the rate specified in the legally sanctioned exchange market. It } \\
\text { is calculated as an annual average based on monthly averages (local currency } \\
\text { units relative to the U.S. dollar). }\end{array}$ & $\begin{array}{l}\text { IDR/USD, } \\
\text { MYR/USD; } \\
\text { THB/USD; and } \\
\text { PHP/USD }\end{array}$ \\
\hline $\begin{array}{l}\text { Unemploy } \\
\text { ment rate }\end{array}$ & $\begin{array}{l}\text { Unemployment, total (\% of the total labour force) (national estimate). } \\
\text { Unemployment refers to the share of the labour force that is without work but } \\
\text { available for and seeking employment. }\end{array}$ & Per cent (\%). \\
\hline $\begin{array}{l}\text { Total } \\
\text { export }\end{array}$ & $\begin{array}{l}\text { Exports of goods and services (constant } 2010 \text { US\$). Exports of goods and } \\
\text { services represent the value of all goods and other market services provided to } \\
\text { the rest of the world. They include the value of merchandise, freight, insurance, } \\
\text { transport, travel, royalties, license fees, and other services, such as } \\
\text { communication, construction, financial, information, business, personal, and } \\
\text { government services. They exclude compensation of employees and investment } \\
\text { income (formerly called factor services) and transfer payments. }\end{array}$ & $\begin{array}{l}\text { Data are in } \\
\text { constant U.S. } \\
\text { dollars. }\end{array}$ \\
\hline $\begin{array}{l}\text { Real } \\
\text { interest } \\
\text { rate }\end{array}$ & $\begin{array}{l}\text { The real interest rate is the lending interest rate adjusted for inflation as } \\
\text { measured by the GDP deflator. The terms and conditions attached to lending } \\
\text { rates differ by country, however, limiting their comparability. }\end{array}$ & Per cent (\%). \\
\hline Inflation & $\begin{array}{l}\text { Inflation, as measured by the consumer price index, reflects the annual } \\
\text { percentage change in the cost to the average consumer of acquiring a basket of } \\
\text { goods and services that may be fixed or changed at specified intervals, such as } \\
\text { yearly. The Laspeyres formula is generally used. }\end{array}$ & Per cent (\%). \\
\hline $\begin{array}{l}\text { Total } \\
\text { national } \\
\text { saving }\end{array}$ & $\begin{array}{l}\text { Net national savings are equal to gross national savings less than the value of } \\
\text { consumption of fixed capital. }\end{array}$ & $\begin{array}{l}\text { Net national } \\
\text { saving is in } \\
\text { current U.S. } \\
\text { dollars. }\end{array}$ \\
\hline $\begin{array}{l}\text { Real } \\
\text { national } \\
\text { saving }\end{array}$ & $\begin{array}{l}\text { Total national saving/Consumer Price Index. The Laspeyres formula is generally } \\
\text { used (Consumer Price Index; } 2010=100 \text { ). }\end{array}$ & $\begin{array}{l}\text { Net national } \\
\text { saving is in } \\
\text { constant U.S. } \\
\text { dollars. }\end{array}$ \\
\hline $\begin{array}{l}\text { GDP } \\
\text { Growth }\end{array}$ & $\begin{array}{l}\text { The annual percentage growth rate of GDP at market prices based on constant } \\
\text { local currency. Aggregates are based on constant } 2010 \text { U.S. dollars. GDP is the } \\
\text { sum of gross value added by all resident producers in the economy plus any } \\
\text { product taxes and minus any subsidies not included in the value of the products. } \\
\text { It is calculated without making deductions for depreciation of fabricated assets } \\
\text { or depletion and degradation of natural resources. }\end{array}$ & Per cent (\%). \\
\hline
\end{tabular}

Source: The World Bank and Author Data Set 


\section{Cahyadin \& Ratwianingsih}

External Debt, Exchange Rate, and Unemployment in Selected ASEAN Countries

ARDL-ECM was formulated to explain the effect of explanatory variables of the equation of external debt, exchange rate, and unemployment. The empirical model of the exchange rate can be seen in Parveen et al., (2012), Patel et al., (2014) and Abdoh, et al. (2016). Meanwhile, the empirical model of the external debt refers to Mupunga and Roux (2014); Awan et al., (2015); Abdullahi et al., (2015); and Lau and Lee (2016). Furthermore, the empirical model of unemployment has been conducted by Dalmar et al., (2017) and Puspadjuita (2018).

The basic model of ARDL-ECM has been developed by Pesaran and Shin (1995). In addition, Pesaran, Shin, and Smith (2001) have also developed an analysis of Bounds Test to ARDL equation. All research variables would take part in a stationarity test (unit-roots) by employing the Augmented Dickey-Fuller (ADF) and Phillips-Perron (PP) test (Maddala and Kim, 2004). The last step of ARDL analysis is the stability test using CUSUM and CUSUMQ (Pesaran and Pesaran, 1997 in Alimi, 2014).

However, the explanation of the co-movement and counter-movement between external debt, exchange rate, and unemployment utilized the result of the ARDL-ECM estimation and Granger Causality Test. The basic Granger Causality Test (GCT) model refers to Gujarati and Porter (2009). The definition of co-movement is the movement of external debt, exchange rate, and unemployment contribute positively to each other. For example, if the exchange rate undergoes appreciation, then the external debt of the ASEAN 4 countries tends to decrease. Moreover, if the unemployment decreases, then the external debt burden of the ASEAN 4 countries decreases. Besides, if the exchange rate is appreciated, unemployment tends to decrease. Meanwhile, the definition of countermovement is the negative contributing conditions between external debt, exchange rate, and unemployment in ASEAN 4.

The ARDL-ECM estimation equations of external debt, exchange rate, and unemployment are shown in equations $1 \mathrm{a}, 1 \mathrm{~b}, 1 \mathrm{c}$, respectively:

$$
\begin{aligned}
& \Delta \mathrm{RED}_{\mathrm{t}}=a+\sum_{\mathrm{i}=1}^{\mathrm{n}} \mathrm{b}_{\mathrm{i}} \Delta \mathrm{RED}_{\mathrm{t}-1}+\sum_{\mathrm{i}=1}^{\mathrm{n}} \mathrm{c}_{\mathrm{i}} \Delta \operatorname{RIR}_{\mathrm{t}-\mathrm{i}}+\sum_{\mathrm{i}=1}^{\mathrm{n}} \mathrm{d}_{\mathrm{i}} \Delta \mathrm{ER}_{\mathrm{t}-\mathrm{i}}+\sum_{\mathrm{i}=1}^{\mathrm{n}} \mathrm{e}_{\mathrm{i}} \Delta \mathrm{RNS}_{\mathrm{t}-\mathrm{i}}+\beta_{1} \mathrm{RED}_{\mathrm{t}-1}+\beta_{2} \mathrm{RIR}_{\mathrm{t}-1}+\beta_{3} \mathrm{ER}_{\mathrm{t}-1}+\beta_{4} \mathrm{RNS}_{\mathrm{t}-1}+\varepsilon_{\mathrm{t}} \\
& \Delta \mathrm{ER}_{\mathrm{t}}=a+\sum_{\mathrm{i}=1}^{\mathrm{n}} \mathrm{b}_{\mathrm{i}} \Delta \mathrm{ER}_{\mathrm{t}-1}+\sum_{\mathrm{i}=1}^{\mathrm{n}} \mathrm{c}_{\mathrm{i}} \Delta \mathrm{X}_{\mathrm{t}-\mathrm{i}}+\sum_{\mathrm{i}=1}^{\mathrm{n}} \mathrm{d}_{\mathrm{i}} \Delta \mathrm{RIR} \mathrm{t}_{\mathrm{t}-\mathrm{i}}+\sum_{\mathrm{i}=1}^{\mathrm{n}} \mathrm{e}_{\mathrm{i}} \Delta \mathrm{INF}_{\mathrm{t}-\mathrm{i}}+\sum_{\mathrm{i}=1}^{\mathrm{n}} \mathrm{f}_{\mathrm{i}} \Delta \mathrm{RED}_{\mathrm{t}-\mathrm{i}}+\beta_{\mathrm{1}} \mathrm{ER}_{\mathrm{t}-1}+\beta_{2} \mathrm{X}_{\mathrm{t}-1}+\beta_{3} \mathrm{RIR}_{\mathrm{t}-1}+\beta_{4} \mathrm{INF}_{\mathrm{t}-1}+\beta_{\mathrm{S}} \mathrm{RED}_{\mathrm{t}-1}+\varepsilon_{\mathrm{t}} \\
& \Delta \mathrm{UER}_{\mathrm{t}}=a+\sum_{\mathrm{i}=1}^{\mathrm{n}} \mathrm{b}_{\mathrm{i}} \Delta \mathrm{UER}_{\mathrm{t}-\mathrm{i}}+\sum_{\mathrm{i}=1}^{\mathrm{n}} \mathrm{c}_{\mathrm{i}} \Delta \mathrm{GDPG}_{\mathrm{t}-\mathrm{i}}+\sum_{\mathrm{i}=1}^{\mathrm{n}} \mathrm{d}_{\mathrm{i}} \Delta \mathrm{ER}_{\mathrm{t}-\mathrm{i}}+\sum_{\mathrm{i}=1}^{\mathrm{n}} \mathrm{e}_{\mathrm{i}} \Delta \mathrm{RED}_{\mathrm{t}-\mathrm{i}}+\beta_{1} \mathrm{UER}_{\mathrm{t}-1}+\beta_{2} \mathrm{GDPG}_{\mathrm{t}-1}+\beta_{3} \mathrm{ER}_{\mathrm{t}-\mathrm{i}}+\beta_{4} \mathrm{RED}_{\mathrm{t}-\mathrm{1}}+\varepsilon_{\mathrm{t}}
\end{aligned}
$$

The $\Delta$ explains the change in the value of variables. Furthermore, $\mathrm{a}$ is the constants or intercept of the ARDL-ECM model, while b, $c, d, e, f$, and $\beta$ are the coefficients/parameters of independent variables. The " $\mathrm{t}$ " is the research period from 1980-2017, and $\varepsilon$ is the error term of ARDL-ECM. 


\section{Cahyadin \& Ratwianingsih}

External Debt, Exchange Rate, and Unemployment in Selected ASEAN Countries

The three equations can be formulated into ARDL estimation models, as follows (equation $2 \mathrm{a}, 2 \mathrm{~b}$, and $2 \mathrm{c})$ :

$$
\begin{aligned}
& \operatorname{RED}_{\mathrm{t}}=a+\sum_{\mathrm{i}=1}^{\mathrm{n}} \mathrm{b}_{\mathrm{i}} \mathrm{RED}_{\mathrm{t}-\mathrm{i}}+\sum_{\mathrm{i}=1}^{\mathrm{n}} \mathrm{c}_{\mathrm{i}} \mathrm{RIR}_{\mathrm{t}-\mathrm{i}}+\sum_{\mathrm{i}=1}^{\mathrm{n}} \mathrm{d}_{\mathrm{i}} \mathrm{ER}_{\mathrm{t}-\mathrm{i}}+\sum_{\mathrm{i}=1}^{\mathrm{n}} \mathrm{e}_{\mathrm{i}} \mathrm{RNS}_{\mathrm{t}-\mathrm{i}}+\varepsilon_{\mathrm{t}} \\
& \mathrm{ER}_{\mathrm{t}}=a+\sum_{\mathrm{i}=1}^{\mathrm{n}} \mathrm{b}_{\mathrm{i}} \mathrm{ER}_{\mathrm{t}-\mathrm{i}}+\sum_{\mathrm{i}=1}^{\mathrm{n}} \mathrm{c}_{\mathrm{i}} \mathrm{X}_{\mathrm{t}-\mathrm{i}}+\sum_{\mathrm{i}=1}^{\mathrm{n}} \mathrm{d}_{\mathrm{i}} \mathrm{RIR}_{\mathrm{t}-\mathrm{i}}+\sum_{\mathrm{i}=1}^{\mathrm{n}} \mathrm{e}_{\mathrm{i}} \operatorname{INF}_{\mathrm{t}-\mathrm{i}}+\sum_{\mathrm{i}=1}^{\mathrm{n}} \mathrm{f}_{\mathrm{i}} \mathrm{RED}_{\mathrm{t}-\mathrm{i}}+\varepsilon_{\mathrm{t}} \\
& \mathrm{UER}_{\mathrm{t}}=a+\sum_{\mathrm{i}=1}^{\mathrm{n}} \mathrm{b}_{\mathrm{i}} \mathrm{UER}_{\mathrm{t}-\mathrm{i}}+\sum_{\mathrm{i}=1}^{\mathrm{n}} \mathrm{c}_{\mathrm{i}} \operatorname{GDPG}_{\mathrm{t}-\mathrm{i}}+\sum_{\mathrm{i}=1}^{\mathrm{n}} \mathrm{d}_{\mathrm{i}} \mathrm{ER}_{\mathrm{t}-\mathrm{i}}+\sum_{\mathrm{i}=1}^{\mathrm{n}} \mathrm{e}_{\mathrm{i}} \operatorname{RED}_{\mathrm{t}-\mathrm{i}}+\varepsilon_{\mathrm{t}}
\end{aligned}
$$

The three ARDL equations show the long-run relationship of research variables in ASEAN 4.

Based on equations $1 a, 1 b$, and 1c, an ECM estimation model can be formulated for the external debt, exchange rate, and unemployment equations in ASEAN 4. The ECM model illustrates the short-term relationship of each equation ( $3 a, 3 b, 3 c)$, as follows:

$$
\begin{gathered}
\Delta \mathrm{RED}_{\mathrm{t}}=a+\sum_{\mathrm{i}=1}^{\mathrm{n}} \gamma_{1 \mathrm{i}} \mathrm{RED}_{\mathrm{t}-\mathrm{i}}+\sum_{\mathrm{i}=1}^{\mathrm{n}} \gamma_{2 \mathrm{i}} \Delta \mathrm{RIR}_{\mathrm{t}-\mathrm{i}}+\sum_{\mathrm{i}=1}^{\mathrm{n}} \gamma_{3 \mathrm{i}} \Delta \mathrm{ER}_{\mathrm{t}-\mathrm{i}}+\sum_{\mathrm{i}=1}^{\mathrm{n}} \gamma_{4 \mathrm{i}} \Delta \mathrm{RNS}_{\mathrm{t}-\mathrm{i}}+\gamma_{5} \mathrm{ECT}_{\mathrm{t}-1}+\varepsilon_{\mathrm{t}} \\
3 \mathrm{a} \\
\Delta \mathrm{ER}_{\mathrm{t}}=a+\sum_{\mathrm{i}=1}^{\mathrm{n}} \gamma_{1 \mathrm{i}} \mathrm{ER}_{\mathrm{t}-\mathrm{i}}+\sum_{\mathrm{i}=1}^{\mathrm{n}} \gamma_{2 \mathrm{i}} \Delta \mathrm{X}_{\mathrm{t}-\mathrm{i}}+\sum_{\mathrm{i}=1}^{\mathrm{n}} \gamma_{3 \mathrm{i}} \Delta \mathrm{RIR}_{\mathrm{t}-\mathrm{i}}+\sum_{\mathrm{i}=1}^{\mathrm{n}} \gamma_{4 \mathrm{i}} \Delta \mathrm{INF}_{\mathrm{t}-\mathrm{i}}+\sum_{\mathrm{i}=1}^{\mathrm{n}} \gamma_{5 \mathrm{i}} \Delta \mathrm{RED}_{\mathrm{t}-\mathrm{i}}+\gamma_{6} \mathrm{ECT}_{\mathrm{t}-1}+\varepsilon_{\mathrm{t}} \\
3 \mathrm{~b} \\
\Delta \mathrm{UER}_{\mathrm{t}}=a+\sum_{\mathrm{i}=1}^{\mathrm{n}} \gamma_{1 \mathrm{i}} \mathrm{UER}_{\mathrm{t}-\mathrm{i}}+\sum_{\mathrm{i}=1}^{\mathrm{n}} \gamma_{2 \mathrm{i}} \Delta \mathrm{GDPG}_{\mathrm{t}-\mathrm{i}}+\sum_{\mathrm{i}=1}^{\mathrm{n}} \gamma_{3 \mathrm{i}} \Delta \mathrm{ER}_{\mathrm{t}-\mathrm{i}}+\sum_{\mathrm{i}=1}^{\mathrm{n}} \gamma_{4 \mathrm{i}} \Delta \mathrm{RED}_{\mathrm{t}-\mathrm{i}}+\gamma_{5} \mathrm{ECT}_{\mathrm{t}-1}+\varepsilon_{\mathrm{t}} \\
3 \mathrm{c}
\end{gathered}
$$

The $\gamma$ is the coefficient/parameter of the independent variables. Meanwhile, ECT is the error correction term of the short-term ECM Model. The value of $\gamma_{5}$ should be negative and significant.

The final stage of the analysis in this research was the Granger Causality Test (GCT). Based on the basic GCT model in Gujarati and Porter (2009), the GCT models between external debt, exchange rate, and unemployment in ASEAN 4 are as follows:

$$
\begin{aligned}
& \hat{\operatorname{RED}}_{\mathrm{t}}=\sum_{\mathrm{i}=1}^{\mathrm{n}} \alpha_{\mathrm{i}} \hat{\operatorname{ER}}_{\mathrm{t}-\mathrm{i}}+\sum_{\mathrm{j}=1}^{\mathrm{n}} \beta_{\mathrm{j}} \hat{\operatorname{UER}}_{\mathrm{t}-\mathrm{j}}+\sum_{\mathrm{k}=1}^{\mathrm{n}} \gamma_{\mathrm{k}} \hat{\operatorname{RED}}_{\mathrm{t}-\mathrm{k}}+\varepsilon_{1 \mathrm{t}} \\
& \hat{\operatorname{ER}}_{\mathrm{t}}=\sum_{\mathrm{i}=1}^{\mathrm{n}} \alpha_{\mathrm{i}} \hat{\operatorname{ER}}_{\mathrm{t}-\mathrm{i}}+\sum_{\mathrm{j}=1}^{\mathrm{n}} \beta_{\mathrm{j}} \hat{\operatorname{UER}}_{\mathrm{t}-\mathrm{j}}+\sum_{\mathrm{k}=1}^{\mathrm{n}} \gamma_{\mathrm{k}} \hat{\operatorname{RED}}_{\mathrm{t}-\mathrm{k}}+\varepsilon_{2 \mathrm{t}} \\
& \hat{\operatorname{UER}}_{\mathrm{t}}=\sum_{\mathrm{i}=1}^{\mathrm{n}} \alpha_{\mathrm{i}} \hat{\operatorname{ER}}_{\mathrm{t}-\mathrm{i}}+\sum_{\mathrm{j}=1}^{\mathrm{n}} \beta_{\mathrm{j}} \hat{\operatorname{UER}}_{\mathrm{t}-\mathrm{j}}+\sum_{\mathrm{k}=1}^{\mathrm{n}} \gamma_{\mathrm{k}} \hat{\operatorname{RED}}_{\mathrm{t}-\mathrm{k}}+\varepsilon_{3 \mathrm{t}}
\end{aligned}
$$


The " $\wedge$ " symbol on top of the variables in equations 4,5 , and 6 is the fitted value (FT). FT was obtained from the ARDL equations, namely: equation $2 a$ for the fitted value of external debt, equation $2 b$ for the fitted value of exchange rate, and equation $2 c$ for the fitted value of the unemployment rate.

\section{Result and Discussion}

The first procedure of time series data analysis was the unit-roots test. This test was conducted to identify the stationarity of data. The results of the unit-roots test are illustrated in Table 2.

Based on Table 2, it can be inferred that the eight variables in Indonesia have been stationary at the first difference, both from the ADF and PP results. Meanwhile, the other three variables have been stationary at level. These results also occurred in the research variables of Thailand and the Philippines. Furthermore, there were only six stationary variables of Malaysia at the first difference based on ADF, seven stationary variables at the first difference based on $\mathrm{PP}$, and the remaining have been stationary at a level from the result of ADF or PP.

The further testing step of research variables was the cointegration test under the ARDL Bound Test. The result can be seen in Table 3. The basic test of the bound test can refer to Pesaran et al., (2001). The finding showed that the estimation of the external debt equation (Equation 2a), the exchange rate (Equation $2 b$ ), and unemployment (Equation 2c) in ASEAN 4 were significant. It explained that the research variables of the three equations had been cointegrated. Thus, it implied that there was a long-run relationship among variables.

Table 4 describes the ARDL estimation result of the external debt equation in ASEAN 4. The external debt in Indonesia was influenced by the lagged external debt, interest rate, lagged exchange rate, national saving, and lagged national saving. The result confirmed that the current external debt value was influenced by the previous external debt period. Other than that, the depreciation of the IDR/USD exchange rate would impact the increase of the external debt value. Furthermore, insufficient national savings for domestic investment would stimulate external debt policies. It means that the rise in national saving in Indonesia would reduce external debt. The estimation results also occurred in the equation of the external debt of Malaysia, Thailand, and the Philippines. However, external debt in the Philippines was not significantly influenced by the exchange rate. Based on the data of the World Bank, the external debt value of the Philippines tended to decrease in the period of this research. 
Fakhrunnas

Total Financing of Islamic Rural Banks and Regional Macroeconomic Factors: ...

Table 2 Unit Root Test Results of Research Variables in Indonesia, Malaysia, Thailand, and the Philippines

\begin{tabular}{|c|c|c|c|c|c|c|c|c|}
\hline & \multicolumn{4}{|c|}{ Augmented Dickey-Fuller (ADF) test } & \multicolumn{4}{|c|}{ Phillips-Perron (PP) test } \\
\hline & \multicolumn{2}{|c|}{ Level } & \multicolumn{2}{|c|}{ First Difference } & \multicolumn{2}{|c|}{ Level } & \multicolumn{2}{|c|}{ First Difference } \\
\hline & Intercept & $\begin{array}{c}\text { Intercept and } \\
\text { Trend }\end{array}$ & Intercept & $\begin{array}{l}\text { Intercept and } \\
\text { Trend }\end{array}$ & Intercept & $\begin{array}{c}\text { Intercept and } \\
\text { Trend }\end{array}$ & Intercept & $\begin{array}{c}\text { Intercept and } \\
\text { Trend }\end{array}$ \\
\hline \multicolumn{9}{|c|}{ Indonesia } \\
\hline ERIND & -0.57541 & -2.84241 & $-7.15884 *$ & $-7.08668 *$ & -1.50738 & -2.87959 & $-7.18357^{*}$ & $-7.11111 *$ \\
\hline XIND & -2.59538 & -2.64733 & $-4.64679 *$ & $-4.66838^{*}$ & -2.46725 & -2.88714 & $-4.55795^{*}$ & $-4.57856^{*}$ \\
\hline RIRIND & $-5.67136^{*}$ & $-5.7664 *$ & - & - & $-5.66502^{*}$ & $-5.75623^{*}$ & - & - \\
\hline INFIND & $-5.00574 *$ & $-5.02189 *$ & - & - & $-5.00574^{*}$ & $-5.02189 *$ & - & - \\
\hline REDIND & -1.05463 & -1.94394 & $-4.08276^{*}$ & $-4.06387^{* *}$ & -1.05365 & -1.76556 & $-4.15807^{*}$ & $-4.14344 * *$ \\
\hline RNSIND & -1.76087 & -1.84419 & $-6.17848 *$ & $-6.09013^{*}$ & -1.73474 & -1.82143 & $-6.17848^{*}$ & $-6.09013^{*}$ \\
\hline UERIND & -0.87534 & 0.16535 & $-3.51215^{* *}$ & -2.84456 & -1.03226 & -0.04343 & $-3.49773^{* *}$ & $-3.77541 * *$ \\
\hline GDPGIND & $-4.59757^{*}$ & $-4.51361^{*}$ & - & - & $-4.61027^{*}$ & $-4.5275^{*}$ & - & - \\
\hline$\wedge($ ERIND $)$ & -1.20603 & -2.530413 & $-6.325985^{*}$ & $-6.198388^{*}$ & -1.004047 & -2.530413 & $-6.543851^{*}$ & $-6.418461^{*}$ \\
\hline$\wedge($ REDIND) & -0.849923 & -1.021579 & $-3.808097^{*}$ & $-3.765992^{* *}$ & -0.995953 & -1.48694 & $-3.808097^{*}$ & $-3.765992 * *$ \\
\hline$\wedge($ UERIND) & -1.713447 & 0.507276 & $-3.435516^{* *}$ & $-4.270208^{*}$ & -1.438154 & -0.015311 & $-3.49881 * *$ & $-4.290007^{*}$ \\
\hline \multicolumn{9}{|c|}{ Malaysia } \\
\hline ERMYS & -0.86389 & -1.79245 & $-4.84012^{*}$ & $-4.78884 *$ & -1.01386 & -2.0101 & $-4.84640 *$ & $-4.79482^{*}$ \\
\hline XMYS & -1.21074 & -0.48935 & $-5.09034^{*}$ & $-5.28836^{*}$ & -1.21074 & -0.48935 & $-5.09461^{*}$ & $-5.26699 *$ \\
\hline RIRMYS & $-6.43176^{*}$ & $-7.60170 *$ & - & - & $-6.43176^{*}$ & $-7.36353 *$ & - & - \\
\hline INFMYS & $-3.70816^{*}$ & $-3.63675^{* *}$ & - & - & $-3.58832 *$ & $-3.50763^{* *}$ & - & - \\
\hline REDMYS & 0.74269 & -1.00636 & $-5.27106^{*}$ & $-5.50066^{*}$ & 0.69948 & -1.04749 & $-5.26546^{*}$ & $-5.49797^{*}$ \\
\hline RNSMYS & -1.31871 & -2.28932 & $-6.03730 *$ & $-5.98264^{*}$ & -1.29738 & -2.47334 & $-6.05488^{*}$ & $-6.00082 *$ \\
\hline UERMYS & -1.09890 & $-3.86741 * *$ & $-4.17300^{*}$ & $-4.06069^{*}$ & -1.14962 & -1.32842 & $-4.11341^{*}$ & $-4.06069 *$ \\
\hline GDPGMYS & $-4.90324 *$ & $-4.94693 *$ & - & - & $-4.91807^{*}$ & $-4.96297^{*}$ & - & - \\
\hline ^(ERMYS) & -2.223912 & -2.49038 & -2.58391 & -2.393146 & $-4.45533^{*}$ & $-4.47359^{*}$ & $-21.0302^{*}$ & $-21.4196 *$ \\
\hline$\wedge($ REDMYS) & 0.610935 & -1.716146 & $-4.828441^{*}$ & $-4.988879 *$ & 0.610935 & -1.716146 & $-4.842785^{*}$ & $-5.001428 *$ \\
\hline$\wedge$ (UERMYS) & $-3.262918^{* *}$ & $-3.31140^{* * *}$ & - & - & $-9.157963 *$ & $-8.976694 *$ & - & - \\
\hline \multicolumn{9}{|c|}{ Thailand } \\
\hline ERTHA & -1.65753 & -1.39315 & $-4.94339^{*}$ & $-4.95130 *$ & -1.74809 & -1.63554 & $-4.93894^{*}$ & $-4.94184^{*}$ \\
\hline XTHA & -0.3692 & -2.67658 & $-5.90189 *$ & $-5.81553^{*}$ & -0.31010 & -2.79665 & $-6.07364^{*}$ & $-5.98993 *$ \\
\hline RIRTHA & -2.17197 & $-4.20196 * *$ & - & - & -2.15876 & $-4.20096 * *$ & - & - \\
\hline INFTHA & $-5.90445^{*}$ & $-5.78143 *$ & - & - & $-5.95613^{*}$ & $-5.94797^{*}$ & - & - \\
\hline
\end{tabular}


Cahyadin \& Ratwianingsih

External Debt, Exchange Rate, and Unemployment in Selected ASEAN Countries

\begin{tabular}{|c|c|c|c|c|c|c|c|c|}
\hline & \multicolumn{4}{|c|}{ Augmented Dickey-Fuller (ADF) test } & \multicolumn{4}{|c|}{ Phillips-Perron (PP) test } \\
\hline & \multicolumn{2}{|c|}{ Level } & \multicolumn{2}{|c|}{ First Difference } & \multicolumn{2}{|c|}{ Level } & \multicolumn{2}{|c|}{ First Difference } \\
\hline & Intercept & $\begin{array}{l}\text { Intercept and } \\
\text { Trend }\end{array}$ & Intercept & $\begin{array}{l}\text { Intercept and } \\
\text { Trend }\end{array}$ & Intercept & $\begin{array}{l}\text { Intercept and } \\
\text { Trend }\end{array}$ & Intercept & $\begin{array}{l}\text { Intercept and } \\
\text { Trend }\end{array}$ \\
\hline REDTHA & -2.10064 & -2.36443 & $-3.22868 * *$ & $-3.19081^{* * *}$ & -1.77130 & -1.84529 & $-3.22868 * *$ & $-3.19081 * * *$ \\
\hline RNSTHA & -2.53644 & -2.97492 & $-3.72117^{*}$ & $-3.66380 * *$ & -1.51594 & -1.84547 & $-3.81571^{*}$ & $-3.76079 * *$ \\
\hline UERTHA & -2.52866 & $-3.96824 * *$ & $-6.98936^{*}$ & $-6.96808 *$ & $-2.67251^{* * *}$ & $-3.90476 * *$ & $-7.26529 *$ & $-7.24464 *$ \\
\hline GDPGTHA & $-3.17463 * *$ & $-3.56965^{* *}$ & - & - & $-3.17444^{* *}$ & $-3.58876 * *$ & - & - \\
\hline$\wedge($ ERTHA) & $-3.780326 * *$ & $-3.805534 * *$ & $-6.95908^{*}$ & $-6.822821^{*}$ & $-3.780326 * *$ & $-3.817048 * *$ & $-10.78667^{*}$ & $-10.70308 *$ \\
\hline$\wedge($ REDTHA) & $-4.364491 *$ & 1.787678 & $-5.128845^{*}$ & -2.99452 & $-10.76465 *$ & $-6.480503^{*}$ & $-4.975655^{*}$ & $-6.08704^{*}$ \\
\hline ^(UERTHA) & -1.953804 & -2.871546 & $-5.654628^{*}$ & $-5.56234^{*}$ & -1.711567 & -2.841266 & $-5.758768^{*}$ & $-5.753359 *$ \\
\hline \multicolumn{9}{|c|}{ Philippines } \\
\hline ERPHL & -1.54176 & -1.24909 & $-4.67230 *$ & $-4.74921^{*}$ & -1.50739 & -1.54236 & $-4.74037^{*}$ & $-4.79813^{*}$ \\
\hline XPHL & -1.54176 & -1.24909 & $-4.67230 *$ & $-4.74921^{*}$ & -1.50739 & -1.54236 & $-4.74037^{*}$ & $-4.79813^{*}$ \\
\hline RIRPHL & $-6.1411^{*}$ & $-6.13953^{*}$ & - & - & $-6.14264 *$ & $-6.21740 *$ & - & - \\
\hline INFPHL & $-2.78286 * * *$ & -0.89667 & - & - & $-3.89847^{*}$ & $-7.48551^{*}$ & - & - \\
\hline REDPHL & -2.43123 & -1.81413 & $-4.24179 *$ & $-4.63187^{*}$ & $-4.91550 *$ & -1.69755 & $-4.16947^{*}$ & $-6.01226^{*}$ \\
\hline RNSPHL & -0.33817 & $-3.67139 * *$ & $-3.65974^{*}$ & $-4.52779 *$ & -0.97924 & $-7.32705^{*}$ & $-3.63123 *$ & $-4.59842 *$ \\
\hline UERPHL & -0.90941 & -1.91247 & $-5.84677^{*}$ & $-6.09993 *$ & $-2.67892^{* * *}$ & $-3.42952^{* * *}$ & $-12.84930^{*}$ & $-13.70938 *$ \\
\hline GDPGPHL & $-3.23213 * *$ & $-5.87803^{*}$ & - & - & $-3.29671^{* *}$ & $-4.82897^{*}$ & & \\
\hline ^(ERPHL) & -1.330296 & -1.755714 & $-3.985722^{*}$ & $-4.005474^{*}$ & -1.325743 & -1.656696 & $-3.987194 *$ & $-4.005809 *$ \\
\hline$\wedge($ REDPHL) & $-3.119157^{* *}$ & -2.378158 & $-5.079375^{*}$ & $-5.225188^{*}$ & $-3.948421 *$ & -2.39248 & $-5.076459 *$ & $-5.333937 *$ \\
\hline$\wedge(\mathrm{UERPHL})$ & -1.060146 & -1.729828 & $-11.06202^{*}$ & $-10.89954^{*}$ & -1.897426 & $-3.799912^{* *}$ & $-11.67886^{*}$ & $-11.46349 *$ \\
\hline
\end{tabular}

Source: Secondary Data (processed)

Note: 1 . MacKinnon (1996) $* \alpha=1 \% ; * * \alpha=5 \%$; and ${ }^{* * *} \alpha=10 \%$

2. Max. lag is 9 based on Schwarz information criterion

3. Description: $E R=$ exchange rate (LCU/USD); $X=$ Total Export (USD); RIR = real interest rate (\%); RED = Total External Debt/IHK (USD); RNS = Total National Saving/IHK (USD); UER =

Unemployment Rate (\%); GDPG = GDP Growth (\%); INF = Inflation (\%); ${ }^{\wedge}(\mathrm{RED})=$ Fitted Value of Estimation Result from Eq. 2a; ${ }^{\wedge}(\mathrm{ER})=$ Fitted Value of Estimation Result from Eq. 2b; $($ (UER)

$=$ Fitted Value of Estimation Result from Eq. 2c; IND = Indonesia; MYS = Malaysia; THA = Thailand; and PHL = Philippines. 


\section{Fakhrunnas}

Total Financing of Islamic Rural Banks and Regional Macroeconomic Factors: ...

Table 3 ARDL Bound Test of Indonesia, Malaysia, Thailand, and The Philippines

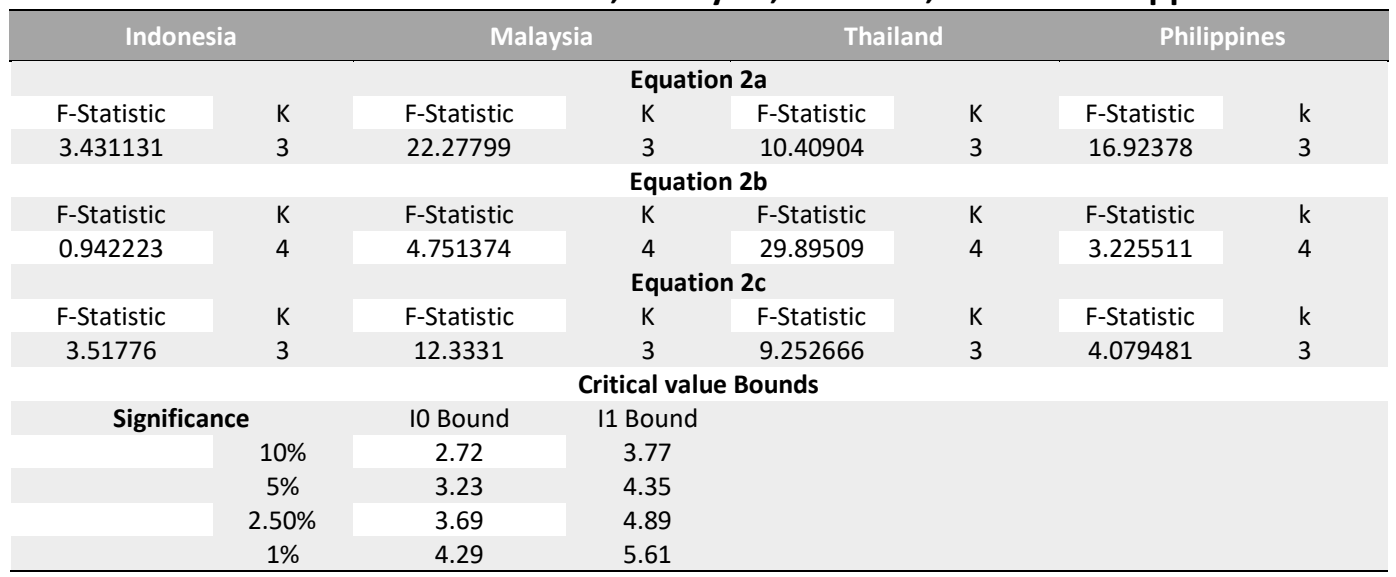

Source: Secondary Data (Processed)

\section{Table 4 ARDL Estimation of Factors Affecting External Debt in ASEAN 4}

\begin{tabular}{|c|c|c|}
\hline Countries & Dependent Var. & Independent Var./Significant \\
\hline \multirow[t]{4}{*}{ Indonesia } & REDIND & REDIND(-1)*; REDIND(-2)**; REDIND(-3)**; REDIND(-4)***; RIRIND**; \\
\hline & & $\operatorname{ERIND}(-1)^{* *} ; \operatorname{ERIND}(-3)^{* *} ; \operatorname{RNSIND*} ; \operatorname{RNSIND}(-1)^{*} ; \operatorname{RNSIND}(-2)^{* *}$ \\
\hline & F-Statistic & $160.2296 *$ \\
\hline & Adjusted $\mathrm{R}^{2}$ & 0.989129 \\
\hline \multirow[t]{3}{*}{ Malaysia } & REDMYS & $\begin{array}{l}\text { REDMYS(-1)*; REDMYS(-3)*; REDMYS(-4)*; RIRMYS(-1)**; ERMYS*; ERMYS(-1)***; } \\
\text { ERMYS(-4)*; RNSMYS(-1)**; RNSMYS(-3)*; RNSMYS(-4)* }\end{array}$ \\
\hline & F-Statistic & $565.2941 *$ \\
\hline & Adjusted $\mathrm{R}^{2}$ & 0.996908 \\
\hline \multirow[t]{3}{*}{ Thailand } & REDTHA & $\begin{array}{l}\text { REDTHA }(-1)^{*} ; \operatorname{RIRTHA}(-1)^{* *} ; \operatorname{RIRTHA}(-2)^{* *} ; \operatorname{RIRTHA}(-3)^{*} ; \operatorname{ERTHA} ; \operatorname{RNSTHA}(-2)^{* *} ; \\
\operatorname{RNSTHA}(-4)^{* *}\end{array}$ \\
\hline & F-Statistic & $57.47605^{*}$ \\
\hline & Adjusted $\mathrm{R}^{2}$ & 0.970222 \\
\hline \multirow[t]{3}{*}{ Philippines } & REDPHL & $\mathrm{C}^{*} ; \mathrm{REDPHL}(-1)^{*} ; \mathrm{RIRPHL}{ }^{* *} ; \mathrm{RIRPHL}(-3)^{* * *} ; \mathrm{RNSPHL} * * * \operatorname{RNSPHL}(-4)^{* *}$ \\
\hline & F-Statistic & $118.7267^{*}$ \\
\hline & Adjusted $\mathrm{R}^{2}$ & 0.980954 \\
\hline
\end{tabular}

Source: Secondary Data (processed)

Note: a. Dependent variable = REDIND; REDMYS; REDTHA; and REDPHL (see APPENDIX, Table A)

b. Sig. * $\alpha=1 \%$; ${ }^{* *} \alpha=5 \%$; ${ }^{* * *} \alpha=10 \%$

Table 5 ARDL Estimation of Factors Affecting Exchange Rate in ASEAN 4

\begin{tabular}{|c|c|c|}
\hline Countries & Dependent Var. & Independent Var./Significant \\
\hline \multirow[t]{3}{*}{ Indonesia } & ERIND & XIND***; RIRIND***; INFIND*** \\
\hline & F-Statistic & 47.01245 \\
\hline & Adjusted $\mathrm{R}^{2}$ & 0.97402 \\
\hline \multirow[t]{3}{*}{ Malaysia } & ERMYS & $\begin{array}{l}\text { ERMYS(-1)*; ERMYS(-2)**; XMYS*; XMYS(-3)*; XMYS(-4)*; RIRMYS***; RIRMYS(- } \\
2)^{*} ; \text { RIRMYS(-3)*; INFMYS**; INFMYS(-1)***; INFMYS(-3)**; INFMYS(-4)* }\end{array}$ \\
\hline & F-Statistic & $161.9983 *$ \\
\hline & Adjusted $\mathrm{R}^{2}$ & 0.993028 \\
\hline \multirow[t]{3}{*}{ Thailand } & ERTHA & $\begin{array}{l}\text { XTHA***; XTHA }(-3)^{* *} ; \operatorname{RIRTHA}(-1)^{* *} ; \operatorname{RIRTHA}(-3)^{* * *} ; \operatorname{RIRTHA}(-4)^{* *} ; \operatorname{INFTHA} * * * ; \\
\text { INFTHA }(-1)^{* *} ; \operatorname{REDTHA}{ }^{* *} ; \operatorname{REDTHA}(-1)^{* * *}\end{array}$ \\
\hline & F-Statistic & $35.23235^{*}$ \\
\hline & Adjusted $\mathrm{R}^{2}$ & 0.961010 \\
\hline \multirow[t]{3}{*}{ Philippines } & ERPHL & $\begin{array}{l}\mathrm{C}^{*} ; \operatorname{ERPHL}(-1)^{*} ; \mathrm{XPHL} * \text { XPHL(-1)*; RIRPHL(-1)*; }{ }^{*} \text { RIRPHL(-2)*; REDPHL*; } \\
\text { REDPHL(-4)** }\end{array}$ \\
\hline & F-Statistic & $128.4036^{*}$ \\
\hline & Adjusted $\mathrm{R}^{2}$ & 0.980465 \\
\hline
\end{tabular}

Source: Secondary Data (processed)

Note: a. Dependent variable = ERIND; ERMYS; ERTHA; and ERPHL (see APPENDIX, Table B)

b. Sig. * $\alpha=1 \%$; ${ }^{* *} \alpha=5 \%$; *** $\alpha=10 \%$ 
The exchange rate growth in ASEAN 4 was also related to domestic indicators and external debt policies. Based on Table 5, the exchange rate in Indonesia is influenced by export, interest rate, and inflation. This condition also occurred in the exchange rate equation of Malaysia, Thailand, and the Philippines. However, the exchange rates in the three countries were also influenced by the lagged variable of export, interest rate, and external debt. Furthermore, the exchange rate in the Philippines was also influenced by the lagged variable of the exchange rate. The estimation result indicated that the exchange appreciation and depreciation in ASEAN 4 were determined not only by domestic transaction/economic conditions but also by policies and foreign economic transactions of each ASEAN member.

However, the estimation of the unemployment equation in ASEAN 4 is explained in Table 6. Unemployment in Indonesia was influenced by the lagged variable of unemployment, economic growth, exchange rate, and external debt. The estimation results also occurred in the unemployment equation in Malaysia, Thailand, and the Philippines. It means that the economic growth in ASEAN 4 has not been able to stimulate a decline in sustainable unemployment. Besides, the appreciation and depreciation value of the exchange rate also had an impact on the unemployment rate. Therefore, the exchange rate stability in the ASEAN region is expected to reduce the unemployment rate. Moreover, the external debt policies by the ASEAN countries are also expected to be utilized to reducing the unemployment rate through productive investment.

Table 6 ARDL Estimation of Factors Affecting Unemployment in ASEAN 4

\begin{tabular}{|c|c|c|}
\hline Countries & $\begin{array}{l}\text { Dependent } \\
\text { Var. }\end{array}$ & Independent Var./Significant \\
\hline \multirow[t]{3}{*}{ Indonesia } & UERIND & $\begin{array}{l}\operatorname{UERIND}(-1)^{*} ; \operatorname{GDPGIND}(-1)^{* *} ; \operatorname{GDPGIND}(-4)^{*} ; \operatorname{ERIND} * * * ; \operatorname{ERIND}(-1)^{* *} \\
\operatorname{ERIND}(-4)^{* *} ; \operatorname{REDIND*}\end{array}$ \\
\hline & F-Statistic & $56.65208^{*}$ \\
\hline & Adjusted $\mathrm{R}^{2}$ & 0.961461 \\
\hline \multirow[t]{3}{*}{ Malaysia } & UERMYS & $\begin{array}{l}\text { C***; UERMYS }(-2) * * * ; \operatorname{UERMYS}(-4)^{* *} ; \operatorname{GDPGMYS}(-3)^{* * *} ; \operatorname{ERMYS}(-2) * * * ; \\
\text { REDMYS }(-4)^{* * *}\end{array}$ \\
\hline & F-Statistic & $130.0718^{*}$ \\
\hline & Adjusted $\mathrm{R}^{2}$ & 0.991465 \\
\hline \multirow[t]{3}{*}{ Thailand } & UERTHA & C*; UERTHA $(-3)^{* * *} ; \operatorname{GDPGTHA}(-1)^{* *} ; \operatorname{GDPGTHA}(-2)^{* *} ; \operatorname{ERTHA}(-4)^{* *}$ \\
\hline & F-Statistic & $9.262903^{*}$ \\
\hline & Adjusted $\mathrm{R}^{2}$ & 0.794798 \\
\hline \multirow[t]{3}{*}{ Philippines } & UERPHL & $\begin{array}{l}\mathrm{C}^{* *} ; \operatorname{UERPHL}(-1)^{* *} ; \operatorname{UERPHL}(-2)^{*} ; \operatorname{GDPGPHL}(-3)^{*} ; \operatorname{ERPHL} * * ; \operatorname{ERPHL}(- \\
1)^{* * *} ; \operatorname{ERPHL}(-2)^{*} ; \operatorname{ERPHL}(-3)^{*} ; \operatorname{ERPHL}(-4)^{*} ; \operatorname{REDPHL}{ }^{* *} ; \operatorname{REDPHL}(-1)^{* *} ; \\
\operatorname{REDPHL}(-4)^{* * *}\end{array}$ \\
\hline & F-Statistic & 18.38879 \\
\hline & Adjusted $\mathrm{R}^{2}$ & 0.911539 \\
\hline
\end{tabular}

Source: Secondary Data (processed)

Note: a. Dependent variable = UERIND; UERMYS; UERTHA; and UERPHL (see APPENDIX, Table C)

b. Sig. * $\alpha=1 \%$; ** $\alpha=5 \%$; *** $\alpha=10 \%$ 
Table 7 ECM Estimation of Factors Affecting External Debt in ASEAN 4

\begin{tabular}{|c|c|c|}
\hline Countries & Dependent Var. & Independent Var./Significant \\
\hline Indonesia & REDIND & $\begin{array}{l}\mathrm{D}(\mathrm{REDIND}(-2))^{* *} ; \mathrm{D}(\operatorname{REDIND}(-3))^{* * *} ; \mathrm{D}(\mathrm{RIRIND})^{*} ; \mathrm{D}(\mathrm{RIRIND}(- \\
1))^{*} ; \mathrm{D}(\mathrm{ERIND}(-2))^{* *} ; \mathrm{D}(\mathrm{RNSIND}) * ; \mathrm{D}\left(\mathrm{RNSIND}(-1)^{* *} ; \mathrm{ECT}(-1) \text {. }\right. \\
\text { ECT(-1) has a negative sign but not significant. }\end{array}$ \\
\hline Malaysia & REDMYS & $\begin{array}{l}\mathrm{D}(\text { REDMYS }(-3))^{*} ; \mathrm{D}(\mathrm{RNSMYS}(-2))^{*} ; \mathrm{D}(\mathrm{RNSMYS}(-3))^{* *} ; \mathrm{ECT}(- \\
1)^{*}\end{array}$ \\
\hline Thailand & REDTHA & $\mathrm{D}(\mathrm{RNSTHA}(-1))^{* *} ; \mathrm{D}(\mathrm{RNSTHA}(-3))^{* *} ; \mathrm{ECT}(-1)^{*}$ \\
\hline Philippines & REDPHL & $\mathrm{D}(\mathrm{RNSPHL})^{* *} ; \mathrm{D}(\mathrm{RNSPHL}(-3))^{* *} ; \mathrm{ECT}(-1)^{*}$ \\
\hline
\end{tabular}

Source: Secondary Data (processed)

Note: a. Dependent variable = REDIND; REDMYS; REDTHA; and REDPHL (see APPENDIX, Table D)

b. Long-run Coefficient (Cointeq):

1. Indonesia; Cointeq = REDIND - $(127111212.8597 *$ RIRIND + 37414.2218*ERIND +3.2351*RNSIND + 85174821.8961)

2. Malaysia; Cointeq = REDMYS $-(44270512.1281 *$ RIRMYS $-7194637.4241 *$ ERMYS +5.9761*RNSMYS 411543399.8824)

3. Thailand; Cointeq $=$ REDTHA $-(81751912.5232 *$ RIRTHA $-13758849.4414 *$ ERTHA +4.4317*RNSTHA 567039017.7702)

4. Philippines; Cointeq $=$ REDPHL $-(1085033.1695 *$ RIRPHL $\quad-5218884.0436 *$ ERPHL-0.1933*RNSPHL + 1047758733.6311)

c. Sig. * $\alpha=1 \% ; * * \alpha=5 \%$; ** $\alpha=10 \%$

This research also used the ECM method to examine the short-term effect of the external debt, exchange rate, and unemployment equation in ASEAN 4. Table 7 describes the estimation result of the external debt equation in ASEAN 4. The external debt in Indonesia was influenced by changes in external debt value, changes in interest rate, change in the exchange rate, and exchange in national saving value. This estimation result was different from the estimation of the external debt equation in Malaysia, Thailand, and the Philippines. For example, in the short term, the external debt in Malaysia was influenced by lagged of external debt and national savings. Meanwhile, in the short term, the exchange rate in Thailand and the Philippines was influenced by national saving and lagged national saving. The variable in the ECM equation that formed the equation was ECT. The ECT(-1) value of the external debt equation of the three countries was negative and significant.

Table 8 ECM Estimation of Factors Affecting Exchange Rate in ASEAN 4

\begin{tabular}{|c|c|c|}
\hline Countries & Dependent Var. & Independent Var./Significant \\
\hline Indonesia & ERIND & $\begin{array}{l}\mathrm{D}(\mathrm{XIND})^{* * *} ; \mathrm{D}(\mathrm{RIRIND})^{* * *} ; \mathrm{D}(\mathrm{INFIND})^{* * *} ; \mathrm{ECT}(-1) \\
\mathrm{ECT}(-1) \text { has } \text { a negative sign but not significant. }\end{array}$ \\
\hline Malaysia & ERMYS & 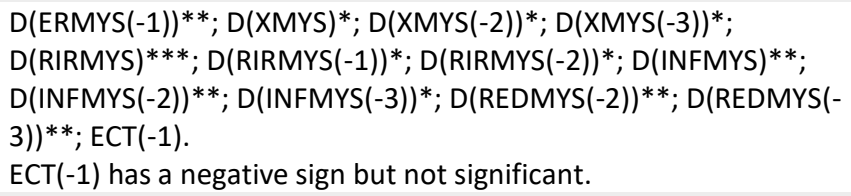 \\
\hline Thailand & ERTHA & $\begin{array}{l}\text { D(XTHA)**; D(XTHA }(-2))^{* *} ; \mathrm{D}(\mathrm{RIRTHA}(-2))^{* *} ; \mathrm{D}(\operatorname{RIRTHA}(-3))^{* *} ; \\
\text { D(INFTHA)**; D(REDTHA) }{ }^{* *} ; \mathrm{ECT}(-1)^{*}\end{array}$ \\
\hline Philippines & ERPHL & $\mathrm{D}(\mathrm{ERPHL}(-3))^{* *} ; \mathrm{D}(\mathrm{RIRPHL}(-1))^{*} ; \mathrm{D}(\mathrm{INFPHL}(-1))^{*} ; \mathrm{ECT}(-1)^{* *}$ \\
\hline
\end{tabular}

Source: Secondary Data (processed)

Note: a. Dependent variable = ERIND; ERMYS; ERTHA; and ERPHL (see APPENDIX, Table E)

b. Long-run Coefficient (Cointeq):

1. Indonesia: Cointeq $=$ ERIND $-(-0.0000 *$ RXIND + 1148.2908*RIRIND + 3539.0335*INFIND + 0.0000*REDIND $+8466.1245)$ 
Cahyadin \& Ratwianingsih

External Debt, Exchange Rate, and Unemployment in Selected ASEAN Countries

2. Malaysia: Cointeq $=$ ERMYS $-(2.2656 *$ LOG(RXMYS) $-1.2733 *$ RIRMYS $+0.6904 *$ INFMYS $2.4975 *$ LOG(REDMYS) + 8.3485)

3. Thailand: Cointeq $=$ LOG $($ ERTHA $)-(0.5798 *$ LOG $($ RXTHA $)+0.0734 *$ RIRTHA $+0.0398 *$ INFTHA $0.2980 *$ LOG(REDTHA) -2.9915 )

4. Philippines: Cointeq $=$ ERPHL $-(0.0000 *$ RXPHL $+0.3492 *$ RIRPHL $-2.6295 *$ INFPHL-0.0000*REDPHL + 23.3563)

c. Sig. ${ }^{*} \alpha=1 \%$; $* * \alpha=5 \%$; $* * \alpha=10 \%$

Table 8 shows that the estimation result of the exchange rate in ASEAN 4 uses ECM. The exchange rate in Indonesia was influenced by export, interest rate, and inflation. The three variables were also influential to the exchange rate in Malaysia. Besides, the shortterm effect in the form of ECT occurred in two other countries: Thailand and the Philippines. For instance, the exchange rate in Thailand was influenced by export, interest rate, inflation, external debt, and ECT(-1). Moreover, the exchange rate in the Philippines was influenced by the lagged of the exchange rate, interest rate, inflation, and ECT. This result confirmed that the short-term model of the exchange rate in Thailand and the Philippines was precise. The ECT(-1) in both countries was negative and significant.

The ECM estimation results in the unemployment equation in ASEAN 4 can be seen in Table 9. In the short-term, the ECM estimation results in the unemployment equation of Malaysia, and Thailand was precise. It can be seen from the ECT(-1) value, which showed negative and significant. In the two countries, unemployment was influenced by the lagged of unemployment variable, lagged of economic growth variable, and lagged of exchange rate variable. Moreover, unemployment in Indonesia was influenced by the lagged economic growth and exchange rate variable. Furthermore, unemployment in the Philippines was influenced by the lagged of unemployment, economic growth, exchange rate, and external debt variables.

Table 9 ECM Estimation of Factors Affecting Unemployment in ASEAN 4

\begin{tabular}{|c|c|c|}
\hline Countries & $\begin{array}{l}\text { Dependent } \\
\text { Var. }\end{array}$ & Independent Var./Significant \\
\hline Indonesia & UERIND & $\begin{array}{l}\mathrm{D}(\mathrm{GDPGIND}(-2))^{*} ; \mathrm{D}(\mathrm{ERIND}(-3))^{* *} ; \mathrm{ECT}(-1) \\
\mathrm{ECT}(-1) \text { has a negative sign but not significant. }\end{array}$ \\
\hline Malaysia & UERMYS & $\mathrm{D}(\operatorname{UERMYS}(-3))^{* *} ; \mathrm{D}(\mathrm{GDPG}(-2))^{* * *} ; \mathrm{D}(\operatorname{ERMYS}(-1))^{* * *} ; \operatorname{ECT}(-1)^{* *}$ \\
\hline Thailand & UERTHA & D(UERTHA $(-2))^{*} ; \mathrm{D}(\text { GDPGTHA }(-1))^{* *} ; \mathrm{D}(\mathrm{ERTHA}(-3))^{* *} ; \mathrm{ECT}(-1)^{*}$ \\
\hline Philippines & UERPHL & 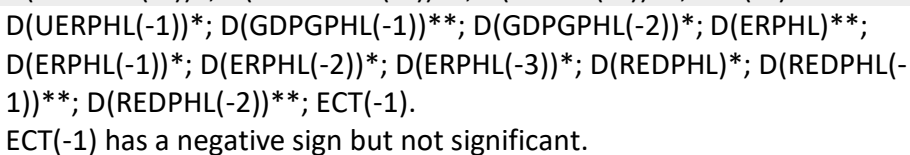 \\
\hline
\end{tabular}

Source: Secondary Data (processed)

Note: a. Dependent variable = UERIND; UERMYS; UERTHA; and UERPHL (see APPENDIX, Table F)

b. Long-run Coefficient (Cointeq):

1. Indonesia: Cointeq $=$ UERIND $-(-12.1315 *$ GDPGIND $+0.0060 *$ ERIND $+0.0000 *$ REDIND -29.5055$)$

2. Malaysia: Cointeq $=$ UERMYS $-\left(0.1344 *\right.$ GDPGMYS $-1.4333^{*}$ ERMYS $-0.0000 *$ REDMYS +8.5838$)$

3. Thailand: Cointeq $=$ UERTHA $-(-0.4856 *$ GDPGTHA $-0.0928 *$ ERTHA $-0.0000 *$ REDTHA + 10.1033)

4. Philippines: Cointeq $=$ UERPHL $-(-1.2220 *$ GDPGPHL $-11.3150 *$ ERPHL-36.0145*REDPHL + 779.1569)

c. Sig. ${ }^{*} \alpha=1 \% ;{ }^{* *} \alpha=5 \% ;{ }^{* * *} \alpha=10 \%$ 
The last step of the ARDL-ECM estimation conducted in this research was the stability test using CUSUM and CUSUMQ. The stability test results of the ARDL equations of each external debt, exchange rate, and unemployment in ASEAN 4 are shown in Appendix Figure $A, B$, and $C$. For example, based on Figure $A$, the ARDL estimation results of the external debt equation in ASEAN 4 has been stable. It indicates that the robustness of the ARDL model has been correct. The results of ARDL estimation stability also occurred in the exchange rate equation (Figure $B$ ) and unemployment (Figure $C$ ) in each of the ASEAN countries.

The empirical findings of the external debt estimation are supported by previous empirical studies such as Mupunga and Roux (2014); Awan et al., (2015); Abdullahi et al., (2015); and Lau and Lee (2016). They exhibited that real interest rate, exchange rate, and national saving had a significant impact on external debt in many countries. The government of ASEAN Countries has insight that the stability of the exchange rate is a significant factor in controlling the level of external debt. Whereas, the competitive real interest rate can attract many creditors to approve external debt contracts. Furthermore, the empirical findings of exchange rate estimation are also revealed by previous empirical studies such as Parveen et al.,(2012), Patel et al., (2014) and Abdoh, et al. (2016). The findings informed that total export, real interest rate, and external debt could restrain the exchange rate volatility among countries. Finally, the results of unemployment estimation are appropriate with some previous empirical studies, such as Dalmar et al., (2017) and Puspadjuita (2018). They described that the high economic growth promoted the low level of unemployment, the stability of the exchange rate could control the level of unemployment, and the high level of external debt in productive sectors led unemployment reduction at a significant level.

The finding of the second step of analysis can be explained by Table 10. It described the result of the Granger Causality Test (GCT) between external debt, exchange rate, and unemployment in ASEAN 4. Based on the table, it can be seen that causality occurred between external debt and the exchange rate in Indonesia, Malaysia, and Thailand. On the other hand, causality occurred between unemployment and external debt in Indonesia, the Philippines, and Thailand. Last, causality also occurred between unemployment and the exchange rate in Indonesia and the Philippines.

Table 10 Granger Causality Test Result

\begin{tabular}{lllll}
\multicolumn{1}{c}{ Variables } & \multicolumn{1}{c}{ Indonesia } & \multicolumn{1}{c}{ Malaysia } & \multicolumn{1}{c}{ Philippines } & Thailand \\
\hline$\wedge($ RED $)-\wedge(E R)$ & No causality & No causality & No causality & Unidirectional \\
$\wedge($ ER $) \wedge($ RED $)$ & Unidirectional & Unidirectional & & No causality \\
$\wedge($ UER $)-\wedge($ RED $)$ & Bidirectional & No causality & No causality & Unidirectional \\
$\wedge($ RED $)-\wedge($ UER $)$ & & & Unidirectional & No causality \\
$\wedge($ UER $)-\wedge(E R)$ & No causality & No causality & No causality & No causality \\
$\wedge($ ER $) \wedge($ UER $)$ & Unidirectional & & Unidirectional & \\
\hline
\end{tabular}

Source: Data analysis

Note: "^" is fitted value from equations $2 a, 2 b$, and $2 c$ 


\section{Conclusion}

In this paper, the relationship between external debt, exchange rate, and unemployment in ASEAN-4 has been explained using the ARDL-ECM and Granger Causality Test (GCT). The analysis used multi-step. It means that there were two steps of analysis. The first step was estimating the external debt, exchange rate, and unemployment model under ARDLECM. Furthermore, the authors estimated the fitted value of external debt, exchange rate, and unemployment using E-views. The second step of the analysis was determining the linkage between external debt, exchange rate, and unemployment under GCT.

The short-term effect in the external debt equation occurred in Malaysia, Thailand, and the Philippines. Meanwhile, the short-term impact on the exchange rate equation arose in Thailand and the Philippines. Finally, the short-term effect in the unemployment equation occurred in Malaysia and Thailand. Meanwhile, based on the ARDL estimation results and stability tests on the external debt equation, the exchange rate and unemployment in ASEAN Countries indicated that the estimation model was precise. It means that there was a tendency of the development of external debt, exchange rate, and unemployment in ASEAN Countries to be a co-movement. Besides, the GCT results between external debt and exchange rates in Indonesia, Malaysia, and Thailand were unidirectional. The causality between unemployment and external debt in the Philippines and Thailand was unidirectional, while in Indonesia, they were bi-direction. Then, the causality between unemployment and exchange rates in Indonesia and the Philippines was indirection.

The result encourages the governments in ASEAN 4 to be able to manage external debt appropriately to stimulate economic growth and decrease the unemployment rate. Furthermore, the supervision of exchange rate appreciation and depreciation can also be carried out through foreign exchange market intervention to maintain the value of external debt and keep the number of unemployment in order not to increase continuously. It means that pro-stability exchange rate policies, pro-poor (control unemployment rate), and control of external debt are the focus of the macroeconomic policies of the government of ASEAN 4 countries.

\section{References}

Abdoh, W. M. Y. M., Yusuf, N H. M., Zulkifli, S. A. M., Bulot, N., \& Ibrahim, N. J. (2016). Macroeconomic Factors that Influence Exchange Rate Fluctuation in ASEAN Countries. International Academic Research Journal of Social Science, 2 (1), 89-94. Retrieved from http://www.iarjournal.com/wp-content/uploads/IARJ-SS-20161-89-94.pdf

Abdullahi, M. M., Bakar, N. A. Bt. A., \& Hasan, S. B. (2015). Determining the Macroeconomic Factors of External Debt Accumulation in Nigeria: An ARDL Bound Test Approach. Procedia-Social and Behavioral Sciences, 211, 745-752. https://doi.org/10.1016/i.sbspro.2015.11.098

Akrasanee, N. (1981). ASEAN Economy 1980: An Overview. Southeast Asian Affairs, 1, 3-16. https://doi.org/10.1355/seaa81a

Alimi, R. S. (2014). ARDL Bounds Testing Approach to Cointegration: A Re-Examination 
of Augmented Fisher Hypothesis in an Open Economy. Asian Journal of Economic Modelling, 2(2), 103-114. Retrieved from https://ideas.repec.org/a/asi/ajemod/2014p103-114.html

Asonuma, T. (2016). Sovereign Defaults, External Debt, and Real Exchange Rate Dynamics. Working Paper IMF No. WP/16/37. Retrieved from https://www.imf.org/en/Publications/WP/Issues/2016/12/31/Sovereign-DefaultsExternal-Debt-and-Real-Exchange-Rate-Dynamics-43737

Aurangzeb \& Asif, K. (2013). Factors Effecting Unemployment: A Cross Country Analysis. International Journal of Academic Research in Business and Social Sciences, 3(1), 219-230. Retrieved from http://hrmars.com/admin/pics/1448.pdf

Awan, R. U., Anjum, A. \& Rahim, S. (2015). An Econometric Analysis of Determinants of External Debt in Pakistan. British Journal of Economics, Management, and Trade, 5 (4), 382391. https://doi.org/10.9734/bjemt/2015/8837

Baharumshah, A. Z., Soon, S.-V. \& Lau, E. (2017). Fiscal sustainability in an emerging market economy: When does public debt turn bad? Journal of Policy Modeling, 39(1), 99113. https://doi.org/10.1016/j.jpolmod.2016.11.002

Benigno, P. \& Romei, F. (2012). Debt Deleveraging and the Exchange Rate. NBER Working Paper Series 17944. https://www.nber.org/papers/w17944.pdf

Bunescu, L. (2014). The Impact of External Debt on Exchange Rate Variation in Romania. Economics and Sociology, 7(3), 104-115. https://doi.org/10.14254/2071-789x.2014/7-3/8

Chang, S.-C. \& Shen, C.-H. (2011). The Effect of Exchange-Rate Uncertainty on Unemployment in Three Developing Asian Countries: Evidence From Bivariate GARCH Approach. Applied Economics Letters, 18(8), 783-788. https://doi.org/10.1080/13504851.2010.498347

Couharde, C., Rey, S. \& Sallenave, A. (2016). External debt and real exchange rates' adjustment in the euro area: new evidence from a nonlinear NATREX model. Journal Applied Economics, 48(11), 966-986. https://doi.org/10.1080/00036846.2015.1090554

Dalmar, M., Ali, A. Y. S. \& Ali, A. A. (2017). Factors Affecting Unemployment in Somalia. Journal of Economics and Sustainable Development, 8(22), 200-210. Retrieved from https://www.iiste.org/Journals/index.php/JEDS/article/view/39799/40918

Draz, M. U. \& Ahmad, F. (2015). External Debts and Exchange Rates of Oil-Producing and Non-Oil-Producing Nations: Evidence from Nigeria and Pakistan. Journal of Advanced Management Science, 3(1), 8-12. https://doi.org/10.12720/joams.3.1.8-12

Faini, R. \& Gressani, D. (1998). Exchange Rate Management and the External Debt Burden: The Case of the Philippines. Review of Development Economics, 2(2), 123-139. https://doi.org/10.1111/1467-9361.00033

Fida, B. A., Khan, M. M. \& Sohall, M. K. (2012). Analysis of Exchange Rate Fluctuations and External Debt: Empirical Evidence from Pakistan. African Journal of Business Management, 6(4), 1760-1768. https://doi.org/10.5897/ajbm11.1283

Floyd, J. E. (2012). Real Exchange Rate and Unemployment within the Euro Area. University of Toronto. Paper Working. Retrieved from https://www.economics.utoronto.ca/jfloyd/euapap/earexemp.pdf

Frenkel, R. \& Ros, J. (2006). Unemployment and the Real Exchange Rate in Latin America. World Development, 34(4), 631-646. https://doi.org/10.1016/j.worlddev.2005.09.007

Gujarati, D. N. \& Porter, D. C. (2009). Basic Econometrics. Fifth Edition, USA: McGraw-Hill Companies.

He, X. (2013). Real Effective Exchange Rate and Unemployment Rate: The Difference between Re-Exporting and Non-Re-Exporting Countries. Thesis. Clemson University. Retrieved from https://tigerprints.clemson.edu/all theses/1716

Lau, E. \& Lee, A. S.-Y. (2016). Determinants of External Debt in Thailand and Philippines. 
Cahyadin \& Ratwianingsih

External Debt, Exchange Rate, and Unemployment in Selected ASEAN Countries

International Journal of Economics and Financial Issues, 6(4), 1973-1980. Retrieved from https://www.econjournals.com/index.php/ijefi/article/view/2151

Maddala, G. S. \& Kim, I.-M. (2004). Unit Roots, Cointegration, and Structural Change. UK: Cambridge University Press.

Mahmud, U. E. (2018). External Debt Burden and Management in the Third World: A Cross-Country Analysis of Nigeria and Indonesia. International Journal of Innovative Research in Social Sciences and Strategic Management Techniques, 5(1), 153-166.

Mupunga, N. \& Roux, P. L. (2014). Analyzing the Theoretical and Empirical Foundations of Public Debt Dynamics in Zimbabwe. ERSA Working Paper, 409, January. Retrieved from https://ideas.repec.org/p/rza/wpaper/409.html

Neaime. (2009). Sustainability of Exchange Rate Policies and External Public Debt in the Mena Region. Journal of Economics and International Finance, 1(2), 059-071. Retrieved from https://academicjournals.org/journal/JEIF/article-abstract/65BC1611899

Nelasco, S. (2012). An Economic Analysis on the External Debt Burden of South Asian Countries. Journal of Educational and Social Research, 2(9), 11-22. Retrieved from http://citeseerx.ist.psu.edu/viewdoc/download?doi=10.1.1.656.1252\&rep=rep1\&type $\equiv \mathrm{pdf}$

Nwanne, T.F.I. \& Richard, E. O. (2015). Assessing the Effect of External Debt Servicing and Receipt on Exchange Rate in Nigeria. International Journal of Economics and Finance, 7(9), 278-286. https://doi.org/10.5539/ijef.v7n9p278

Nyahokwe, O. \& Ncwadi. (2013). Impact of Exchange Rate Volatility on Unemployment in South Africa. Mediterranean Journal of Social Sciences, 4(3), 109-120.

https://doi.org/10.5901/mjss.2013.v4n3p109

Odera, Q. A. (2015). An Analysis on the Effect of External Public Debt on Exchange Rate Volatility in Kenya. Thesis. University of Nairobi. Retrieved from http:// erepository.uonbi.ac.ke/handle/11295/95259

Ogonna, I. C., Idenyi, O., Ifeyinwa, A., \& Gabriel, N. (2016). The Implications of Rising Public Debt on Unemployment in Nigeria: An Auto Regressive Distributed Lag Approach. Asian Research Journal of Arts and Social Sciences, 1(1), 1-15. https://doi.org/10.9734/ariass/2016/26394

Parveen, S., Khan, A. Q. \& Ismail, M. (2012). Analysis of the Factors Affecting Exchange Rate Variability in Pakistan. Academic Research International, 2 (3), 670-674. Retrieved from http://www.savap.org.pk/journals/ARInt./Vol.2(3)/2012(2.3-81).pdf

Patel, P. J., Patel, N. J., \& Patel, A. R. (2014). Factors Affecting Currency Exchange Rate, Economical Formulas and Prediction Models. International Journal of Application or Innovation in Engineering and Management (IJAIEM), 3 (3), 53-56. Retrieved from https://www.ijaiem.org/volume3issue3/IJAIEM-2014-03-05-013.pdf

Pesaran, M. H. \& Shin, Y. (1995). An Autoregressive Distributed Lag Modelling Approach to Cointegration Analysis. The Symposium at the Centennial of Ragnar Frisch. The Norwegian Academy of Science and Letters. Oslo. Retrieved from $\underline{\text { http:/ / citeseerx.ist.psu.edu/viewdoc/download?doi=10.1.1.153.3246\&rep=rep1\&type }}$ $\equiv \mathrm{pdf}$

Pesaran, M.H., Shin, Y \& Smith, R.J. (2001). Bounds testing approaches to the analysis of level relationships. Journal of Applied Econometrics, 16(3), 289-326. https://doi.org/10.1002/jae.616

Puspadjuita, E. A.R. (2018). Factors that Influence the Rate of Unemployment in Indonesia. International Journal of Economics and Finance, 10(1), 140-147.

https://doi.org/10.5539/ijef.v10n1p140

Ramasamy, R. \& Abar, S. K. (2015). Influence of Macroeconomic Variables on Exchange Rate. Journal of Economics and Management, 3(2), 276-281. 
https://doi.org/10.7763/joebm.2015.v3.194

Saheed, Z. S., Sani, I. E., \& Idakwoji, B. O. (2015). Impact of Public External Debt on Exchange Rate in Nigeria. International Finance and Banking, 2 (1), 15-26.

https://doi.org/10.5296/ifb.v2i1.7734

Siregar, R. Y. \& Pontines, V. (2005). External Debt and Exchange Rate Overshooting: The Case of Selected East Asian Countries. Working Paper. The University of Adelaide.

Retrieved from https://ideas.repec.org/p/adl/wpaper/2005-14.html

Yien, L. C., Abdullah, H. \& Azam, M. (2017). Granger Causality Analysis between Inflation, Debt and Exchange Rate: Evidence from Malaysia. International Journal of Academic Research in Accounting, Finance and Management Sciences, 7(1), 189-196.

https://doi.org/10.6007/ijarafms/v7-i1/2624 